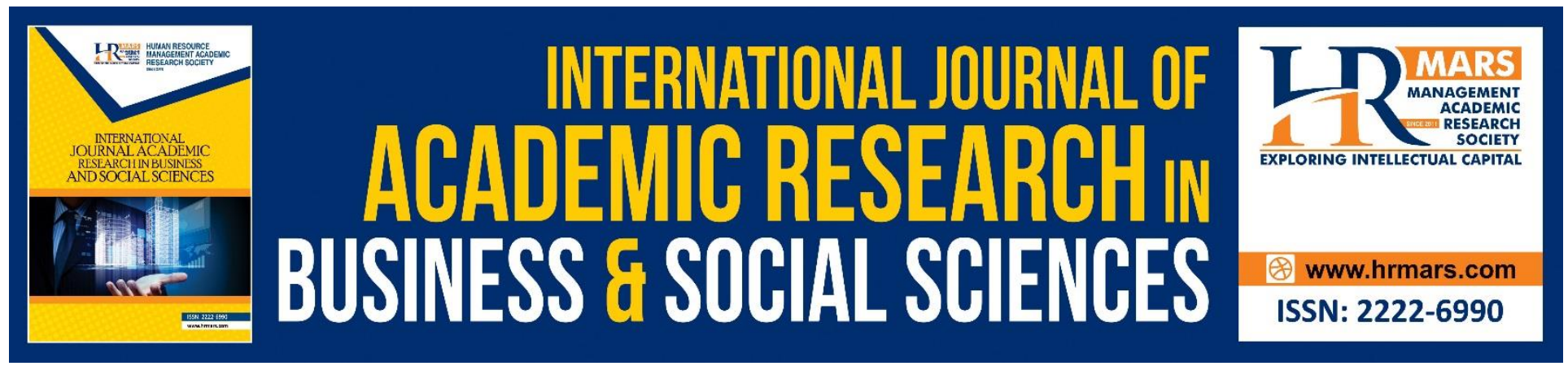

\title{
Analysis of Malay Language Essay Writing Strategy: Application of Levine Motor Planning
}

Fazilah Mat Zain, Shamsuddin Othman, Azhar Md. Sabil, Rozita Radhiah Said

To Link this Article: http://dx.doi.org/10.6007/IJARBSS/v9-i2/5634

DOI: $\quad 10.6007 /$ IJARBSS/v9-i2/5634

Received: 21 Jan 2019, Revised: 19 Feb 2019, Accepted: 22 Feb 2019

Published Online: 26 Feb 2019

In-Text Citation: (Zain, Othman, Sabil, \& Said, 2019)

To Cite this Article: Zain, F. M., Othman, S., Sabil, A. M., \& Said, R. R. (2019). Analysis of Malay Language Essay Writing Strategy: Application of Levine Motor Planning. International Journal of Academic Research in Business and Social Sciences, 9(2), 885-892.

\section{Copyright: (C) 2019 The Author(s)}

Published by Human Resource Management Academic Research Society (www.hrmars.com)

This article is published under the Creative Commons Attribution (CC BY 4.0) license. Anyone may reproduce, distribute, translate and create derivative works of this article (for both commercial and non-commercial purposes), subject to full attribution to the original publication and authors. The full terms of this license may be seen

at: http://creativecommons.org/licences/by/4.0/legalcode

Vol. 9, No. 2, 2019, Pg. 885 - 892

http://hrmars.com/index.php/pages/detail/IJARBSS

JOURNAL HOMEPAGE

Full Terms \& Conditions of access and use can be found at http://hrmars.com/index.php/pages/detail/publication-ethics 


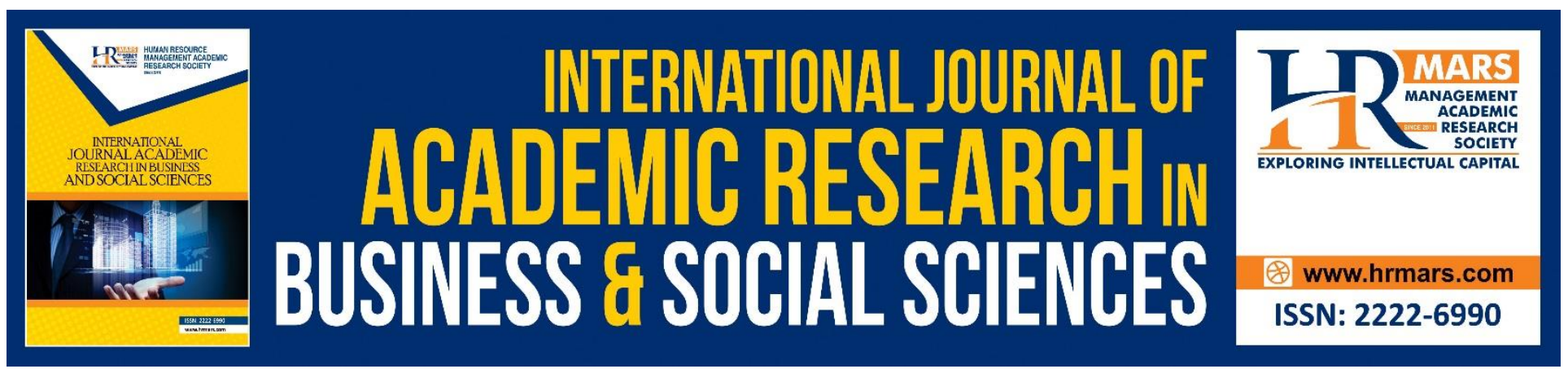

\title{
Analysis of Malay Language Essay Writing Strategy: Application of Levine Motor Planning
}

\section{Fazilah Mat Zain, Shamsuddin Othman, Azhar Md. Sabil, Rozita Radhiah Said}

\author{
Faculty of Educational Studies, Universiti Putra Malaysia, 43400 Serdang, Selangor
}

Email: fazilahmatzain@gmail.com

\begin{abstract}
Writing skills are considered the most difficult skill to teach and comprehend by students. This skill needs a student to think the idea, construct the idea and put the idea appropriately in the writing text. Poor mastery the writing skills may cause the students to think that writing activity is burdensome, therefore the result is gray. Most of the teachers argue that the main problem in writing an essay is the inability of the students to create an idea based on the topic given. Students need to know about the importance of using strategy in essay writing. This concept paper analyzing the essay writing strategy based on Levine Motor Planning. It also discussed the benefits of applying Levine Motor Planning in essay writing strategy. This theory has explained in depth about the brain process during writing. Thus, this paper could be used as a good platform to the teachers who love to explore cognitive writing skill to understand one's mind while they are writing.
\end{abstract}

Keywords: Writing Strategy, Levine Motor Planning, Essay Writing, Malay Language

\section{Introduction}

Rapid globalization and modernization that swept the world has changed the purpose of communication and indirectly has triggers various conflicts to our teaching and learning of Malay Language in school mainly the teaching of writing. Besides the complexity of the students profiles limited reading and exposure to other languages and vast usage of gadgets, that resulted poor vocabulary, less emphasize to speak Malay at home one some factors that cause declining of Malay Language at school especially writing skill. Therefore, specific strategies which are suitable to student need must be identified to enable them to master the four basic skills targeted by the Ministry of Education (Ahmad, 2014).

Ahmad (2014) also finds that the inability to expand writing points, and using good teaching techniques are some of the challenges faced by the level two teachers at primary school. The students are less competence to write. This is due to most teachers play the main role in teaching the writing skills especially in giving the writing points. Teacher control in giving out the points. Teachers 
should focus to the process of writing not to the output only. Therefore, in the teaching of writing skill, the writing process that involved strategies and techniques of writing should be the teachers focus. Inculcating the process writing skill among students must be implemented since early childhood. Students who did not master these skills would not be able to follow the teaching and learning activity effectively.

This matter was supported by Jalil (2016) who emphasized in the importance of students' mastery and learning the writing skill. Mastering writing skill does not only depend on talent, yet it is influenced by systematic and effective teaching. Writing skill can be inculcated and trained to build a skilled writer. The ability to read and write, parts of learning a language is the basic in effective teaching and learning in various knowledge discipline at school (Jamian, 2011). Researchers agreed that is reading and writing literacy is not gained and master skillfully, the risk of failure is in the school system will rise (Whitehurst \& Lonigan, 2001). Thus, shows that the problem of mastering the writing skill must be looked into to find ways to overcome them.

Therefore, according to Pinnel and Fountas (2006), the Levine Motor Planning would give a clear understanding to students about the cognitive process when they are learning a skill which could keep them to plan and implement writing skillfully. It is proved that the TRMPKM theory by Levine is quite new in writing for Malay Language for the primary school students in Malaysia, although in the west it has been applied long ago in teaching and learning. There are four motors emphasized by Levine to achieve a language skill; Levine Motor Planning, Motor Logic, Motor Memory, and Action Motor (Saleh, 2015). In this writing, the researcher has limited the research to Levine Motor Planning only. Thus, one of the main focus of this research paper is to identify the writing strategy which the students used in writing based on the Levine Motor Planning.

\section{Literature Review}

The skill to write an essay is a difficult skill to be target and mastered as it is involving the most complex literacy and high cognitive process (Arshad, 2016; Hassan \& Rahman, 2011; and Baki, 2003). This skill needs a student to think of the idea, draft and writing the text. It is found out that teachers agreed that their main problem for students in writing an essay is the inability to give ideas and generate them to produce a mature writing. This matter is in line with the research by (Bakar, Awal \& Jalaluddin, 2011) which shows that the students writing is not as mature as their age.

According to Zygouris (2001), Tompkins (2008) and Sani (2014) stated that many teachers taught language skill using the same method and theory as they do not have the knowledge about learning and motor differences. This is due to lack of knowledge and understanding regarding learning motor. For example, the LINUS (Literacy and Numeracy) teachers applied the Bandura Theory when they taught reading and writing skill despite the theory is a very general theory in teaching and learning. The consequences is, learning the language is not effective. On the other hand, Withman and Kolleher (2016) also pointed out the students potential could be increased if teachers knew and focus to what happened in a human brain. In their teachers do not understand how the brain function, how the brain receive, filter, combine and use learning for short and long term to help the students to expand their mind as maximum as they could.

The previous research showed that students still did not acquire the skill of essay writing in Malay language (Jamian \& Othman, Mohamad, 2016). This statement is supported by Said (2012) that 
students may writing skill is still poor although they have learnt the aspects for a long period. However, there is no end to this problem, because according to Noralidin (2017), essay writing skill mastery still exists. Thus, research is to see how planning writing strategy is used by primary school students in their writing. Until today, the process writing in Malay Language which focus on mental and writing skill mentalist according to the theory is very limited. This research focused on mentalist writing skill because according Mohamad (2016), this skill is poorly master by the students. This research is looking into usage of mentalist writing strategy among the research participant.

In the Levine theory (2004), the first motor is the Levine Planning Motor which are needs to start a writing assignment. Students complete the task by planning the best strategy. Students should know the importance of wing strategy in writing an essay. Levine's opinion about using strategy to write an essay is in line with the opinion of (Jalil, 2016), that is while writing, they need to be efficient when they apply writing skills' strategy for an essay. If students understand motor learning a skil and therefore could overcome problems while writing. Thus, that is why motor learning theory could be a guidance to plan teaching and learning activity and to develop test (Berninger, 2002). This is because students understanding towards learning motor could help them to comprehend better the strategy in learning a skill.

Learning motor network is a process that takes place in our brain. Levine Motor Planning has connection with one's aim. Before we start learning or writing an essay, students must set target in the mind or then brain should start from the beginning until they have finished the process of writing (final aim). Levine, 2004 explained Mental Controlling Energy (MCE) is the control point for all the four things that control one's mind activity when writing. If their Motor Planning Levine is high, the energy that function to control mental is high too. Lack of one the four items will weaken the energy that controls one's mental and consequently effects one's attention control. MCE is like an engine that move a car without an engine, a car could not function. For example, if a pupil receives an order to write an essay report, the energy that controls her mental focus towards producing an essay which has the characteristic of guided essay as well as keeping on track with the topic. According to Levine also, there are a few matters that influenced one's attention control; that is Awareness Control, Mental Controls Ability, Sleep Awareness Control and Consistency Control. Diagram 1.1 below is the summary for Mental Control Energy.

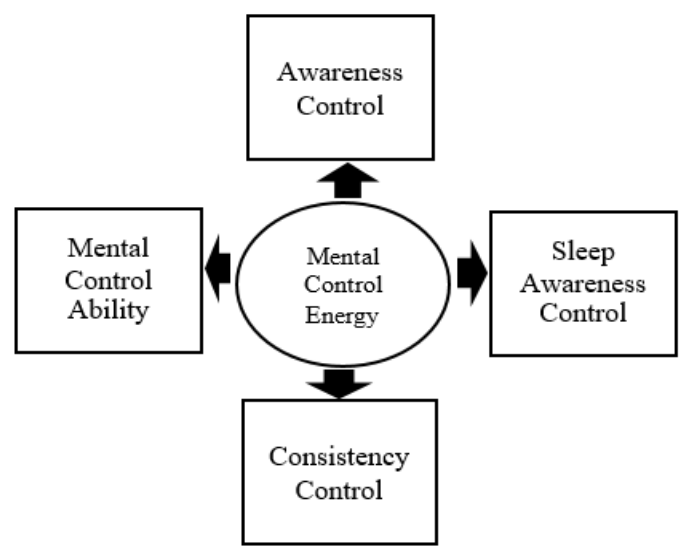

Diagram 1.1 Levine Motor Planning: Mental Control Energy 
Mental Control Energy is important to enable students to feel energetic and could give attention when they are writing an essay better. Students with less mental control energy will feel tired and tend to skip in class. This is because the inability of controlling awareness makes it difficult for the students to be awake. On the other hand, students who have the Mental Control Energy could control her mental to be consistent and ready to complete the task given by their teacher. If students find that they are almost asleep, they will create Awareness Control. However, not all students have a good Mental Control Energy. Students with less ability in Mental Control Energy will have problem in motor planning when they write an essay. Eventhough, the explanation about the assignment by the teacher, these students are lost and they did not know what to write and always ask how to start their writing. Without the Mental Control Energy, students could not write better because they answer the questions without thinking and they did not know how to start the assignment to the designated process.

Besides that, awareness control ensures one's mind to be always ready to write an essay. Students who have Mental Control Energy could control their mental to be consistent and ready to carry out the assignments given by the teacher. Students will draft according to the given question. If they found that they are lost or not focus they will turn to Awareness Control. It is found that those who are weak in Levine Motor Planning, their sentences are in the form of story which is not suitable with the report formats that needs the sentences to be in the form of statements. This is where Awareness Control play its role in reminding the students to write an essay in the correct format.

The Control Consistency drives the students to read the questions, underline clues, proof read and correct the errors. They always remind themselves that they are writing a report and should comply with the characters of writing a report. Students should not write lengthy sentence but write statements and avoid bombastic words. This matter could help the students to comply with the title and the also the essay format.

Therefore, based on the four motors, Planning Motor is the lowest which students master, but if they knew how to connect the logic motor activating long term memory, students could still write a better essay. Students who are weak in Levine Motor Planning must be helped and corrected so they are not left behind. Levine (2003) stated that if student problems when they are planning, they could refer to outside information by referring to the teacher, friends and family, electronic media or printed media. Students could use the materials or media to keep them to get the ideas or to smoothen their writing process. Since writing skill needs one to have high focus, students must have attention control when they are writing.

\section{Principles by Levine Motor Planning}

According to Levine (2003), students with Levine Motor Planning problem could be helped using the four learning activities based on the principles:

One of the principles is to identify the importance of doing something. For example, students should know the importance of writing and the action needed if they are given a task. Students should be told that by mastering the writing skill, they would do a lot of beneficial and meaningful tasks in life and produce better essays; their most important role as a student. The awareness about the importance of writing skill in daily routine will increase Consistency Control and therefore motivate the students to produce essays that comply with teacher need. 
Next is the principle that shows how to carry an assignment. This principle means students show their working process when they are writing. The demonstration should be done before writing an essay; the pre-writing step. This work process should start from underlining the clues to understand the topic, drafting, referring to outside information (teachers, friends, internet, sample essays, magazines etc) to obtain materials or information regarding the topic to start the assignment. Planning the best strategy when they are writing paragraphs, content and closure suitable with the context. Students should allocate time and adhere by it, so they would produce an essay that is in line with the reader and finish within the stipulated time.

The next principle is to say aloud how to carry out the assignment. The teachers should first draft and write down the important notes on the board while explaining verbally about the matter. For instance, while the teacher drafts the important points about 'The Benefits of Reading' on the board, teacher might as well need to carefully explain the points one by one. Lastly the exercising principles verbally and practically. For example, students should be given exercises like pronouncing all the important points. That has been discussed while drafting in front of the class or within their own group. Teachers should observe the students during the presentation or the drilling. Teachers should repeat the discussed the points if the students make mistakes or could not understand the topic.

According to this theory, Levine has perfectly arranged a strategy in order to help those weak students to write better essays through a process that happened in one's mind. The knowledge itself may help teachers to create an intervention in order to help these less capable students in writing. Teachers should be able to unravel hidden talents among the students without focusing on their weaknesses. It is better to unleash their good deeds for them to shine instead of just to focus on their weaknesses.

\section{Discussion}

Students who have been exposed to the Levine's Motor Planning principles will have the ability to write and more attentive towards the arrangements because of the high attentiveness force that they have. This may also help them to create their own plan of a particular assignments given and therefore could master writing skills better. From the perspective of all four motors, Levine's Motor Planning is the lowest but if the students know how to relate logical motors, long term memories activation that thus, they will be able to produce one good essay. Those students who are weak in using Levine's Motor Planning should be corrected and guided one by one to avoid mistakes.

Levine has perfectly arranged the strategy in order to help these weak students to write better essays through a process that happened in one's mind. The knowledge itself may help teacher to create an intervention order to help these less capable students in writing. Teachers should be able to unravel hidden talents among the students without focusing on their weaknesses. It is better to unleash their good deeds for them to shine instead of just focusing on their weakness. Levine's Motor Planning is crucial in order for the students to master mentalist writing skills very well. Nevertheless, a suitable intervention activity should be done for them to produce better writings. The academics experts have suggested some intervention activities to help those students who are having difficulties in Levine's Motor Planning or having difficulties in controlling mental energy. Those who have problems with the latter could be curbed by using suitable interventions. 
According to Tompkin (2008), the usage of TRMPKMM in essay writing may be able to help students to comprehend the step of a particular skills. This study can increase the teachers' knowledge about learning motor writing skills as well as by helping them to plan and carry out better teaching and learning writing skills in Bahasa Melayu. This theory is used because according to (Oliver \& Bowler, 1996; Tompkins 2008) Levine's perspective is well related to the brain process when they are writing. The usage of this theory can able the teachers to understand a better writing skills learning and planning as well as carrying out a good teaching and learning activity.

This study has shown the need and the suitability of the method to curb writing problems in school. Levine Learning Networking Writing Skills Theory in based on the brain can be applied in order to help students to master better writing skill. Through a better first motor mastery, it may help the students to plan better steps and be more interested to the assignments given. Thus, a pupil's mastery is mostly based on teacher's knowledge and comprehension towards the aspects in mentalist's skills. Students can master writing skills successfully and better if they are being exposed to use the principles in the motor.

This study also may increase teachers' knowledge about writing skills learning motor. This knowledge may also help to tune negative perception of a teacher towards the students that may affect their lives. Besides that, the knowledge about this theory may also help these teachers to comprehend writing skills learning better and consequently could plan and carry out a better teaching and learning experience. As a whole, this study can fill in the knowledge gap because it gives a thorough knowledge about mentalist motor learning writing skills theory.

\section{Conclusion}

Above all, this theory can be a guidance for all teachers to help them experience a better teaching and learning process. Due to the scarce study of the theory in our country, thus it is suggested to the teachers and researchers to spread well the usage of this theory to be applied by using quantitative method in order to have a general view on the performance level, mastery, application and the writing skills abilities among the students. Through qualitative method, researchers could study a particular concept, characteristics as well as the criteria in the writing skills mentioned.

\section{Corresponding Author}

Fazilah Mat Zain, Faculty of Educational Studies, University Putra Malaysia, 43400 UPM Serdang, Selangor Darul Ehsan, Malaysia. E-mail: fazilahmatzain@gmail.com

\section{References}

Ahmad, Z. (2014). In Kemahiran menulis: Peningkatan kemahiran dalam kalangan pelajar melalui program 'tinta emas". Proceedings of the Seminar Bahasa Melayu, 146 - 155. 2014.

Arshad, M. (2008). Pendidikan literasi Bahasa Melayu: strategi perancangan dan pelaksanaan. Utusan Publications.

Baki, R. (2003). Pengajaran dan pembelajaran penulisan Bahasa Melayu: senario, teori dan panduan untuk guru dan pelajar. Shah Alam: Karisma Publications Sdn. Bhd.

Bakar, N. A., Awal, N. M., \& Jalaluddin, N. H. (2011). Investigating Malay language writing 
INTERNATIONAL JOURNAL OF ACADEMIC RESEARCH IN BUSINESS AND SOCIAL SCIENCES

Vol. 9, No. 2, Feb, 2019, E-ISSN: 2222-6990 C 2019 HRMARS

proficiency level among upper secondary school students. GEMA Online ${ }^{\circledR}$ Journal of Language Studies, 11(2).

Berninger, V. W., Abbott, R. D., Jones, J., Wolf, B. J., Gould, L., Anderson-Youngstrom, M., \& Apel, K. (2006). Early development of language by hand: Composing, reading, listening, and speaking connections; three letter-writing modes; and fast mapping in spelling. Developmental Neuropsychology, 29(1), 61-92.

Cohen, L. \& Manion, L. (1986). Research methods in education. London: Croom Helm.

Cresswell, J. W. (2005). Planning, conducting and evaluating qualitative and quantitative research (Edisi ke-2.). Malaysia: Pearson Education Pte. Ltd.

Hassan, C. Z. C., \& Rahman, F. A. (2016). Pelaksanaan pengajaran dan pembelajaran kemahiran menulis di sekolah rendah. Jurnal Pendidikan Bahasa Melayu, 1(1), 67-87.

Haq, F. S., Maarof, N., \& Mohd, R. Fauzi Raja Musa (2001). Masalah penulisan naratif di kalangan pelajar sekolah menengah. Jurnal Pendidikan, 27, 3-26.

Jalil, A. G. (2017). In Tingkah laku dan proses semasa menulis karangan respons terbuka murid berprestasi rendah. Proceedings of the ICECRS, 1(1). International Seminar on Generating Knowledge Through Research, UUM-UMSIDA, Universiti Utara Malaysia, Malaysia.

Jamian, A. R. (2016). Permasalahan kemahiran membaca dan menulis Bahasa Melayu muridmurid sekolah rendah di luar bandar. Jurnal Pendidikan Bahasa Melayu, 1(1), 1-12.

Jamian, A. R., Othman, S., \& Hashim, H. (2016). Persepsi guru terhadap penggunaan kartun dalam transformasi pengajaran penulisan karangan bahasa Melayu. Jurnal Pendidikan Bahasa Melayu, 2(1), 128-140.

Levine, M. (1987). Developmental variation and learning disorders. Cambridge and Toronto:

Educators Publishing Service, Inc.

Levine, M. (2002). The myth of laziness. New York: Simon and Schuster

Levine, M. (2012). A mind at a time: How every child can succeed. New York: Simon and Schuster.

Levine, M., \& Barringer, M. D. (2008). Brain-based research helps to identify and treat slow learners. The Education Digest, 73(9), 9.

Mohamed, H. (2016). Meningkatkan kemahiran menulis karangan melalui penggunaan track changes. Malaysian Journal of Learning and Instruction: Vol. 13 (2016): 135-159

Said, R. R., \& Jamian, A. R. (2012). Amalan pengajaran karangan guru cemerlang di dalam bilik darjah: Kajian satu kes pelbagai lokasi. Journal of Educators \& Education/Jurnal Pendidik

dan Pendidikan, 27.

Saleh, Y. (2016). Pembangunan ujian diagnostik kemahiran menulis mekanis Bahasa Melayu. (Tesis Doktor Falsafah). Tanjung Malim: Fakulti Bahasa dan Komunikasi, Universiti

Pendidikan Sultan Idris. 